\title{
Accuracy of the Level of Critical Water Catchment Area for Flood Mitigation Around Bengkulu City, Indonesia
}

\author{
Bambang Sulistyo $^{1^{*}}$, Hery Suhartoyo ${ }^{1}$, Teguh Adiprasetyo ${ }^{1}$, Kanang Setyo Hindarto ${ }^{1}$, and Noviyanti \\ Listyaningrum ${ }^{2}$ \\ ${ }^{1}$ Faculty of Agriculture, University of Bengkulu, Kandang Limun, Bengkulu, Indonesia \\ ${ }^{2}$ Graduate School, University of Gadjah Mada, Bulaksumur, Yogyakarta, Indonesia
}

Received: 2021-01-14 Accepted: 2021-06-07

Keywords:

flood mitigation;

flood disaster;

water catchment;

accuracy

Correspondent email:

bsulistyo@unib.ac.id

\begin{abstract}
Disaster mitigation activities require the availability of a potentially flooded area (PFA) map. One of the causes of flooding is the criticality of water catchment areas; the higher the criticality level, the higher the flooding potential. This study aims to determine the accuracy of the model for determining the PFA around Bengkulu City, which was derived from the Level of Critical Water Catchment Area (LCWCA) model developed by the Ministry of Forestry. After obtaining the LCWCA Map, another analysis was performed in order to obtain the PFA Map. Furthermore, the overlaying was carried out with the Existing Flood Map in such a way that the level of accuracy is known. The threshold values from Justice are used to justify the level of accuracy in three categories, namely Good ( $>85 \%)$, Moderate (70 - 85\%), and Poor $(<70 \%)$. The results showed that in the eight sub-watersheds around the city of Bengkulu, there were two sub -watersheds with reasonable accuracy $(>85 \%$ ), which means that there was $>85 \%$ overlap between areas on the Potentially Flooded Area Map as a result of the analysis of The LCWCA with the area on the Existing Flood Map. There are three sub-watersheds with Moderate accuracy $(70-85 \%)$ and three sub-watersheds with Poor accuracy $(<70 \%)$
\end{abstract}

2021 by the authors. Licensee Indonesian Journal of Geography Indonesh.

This article is an open access article distributed under the terms and conditions of the Creative Commons

Attribution(CC BY NC) licensehttps://creativecommons.org/licenses/by-nc/4.0/.

\section{Introduction}

Floods are natural disasters that are common in Indonesia and in other countries around the world (Tsakiris, 2014); (Oluwasegun, 2017). In Indonesia, the number of disasters caused by flooding is even higher than other types of hydrometeorological disasters such as landslides and tornadoes. As of May 2020, data compiled by the Center for Data Information and Public Relations, the National Disaster Management Agency, reported about 654 disasters (BNPB, 2020). Furthermore, floods are considered unpredictable because they occur suddenly over an uncertain period, except in areas where they frequently occur every year, resulting in losses for the people living around the area. Furthermore, it occurs when the volume of water flowing in a drainage channel or river exceeds the surrounding dry land's flow rate and absorption capacity (Rosyidie, 2013). Every year, the intensity and area of the flood increase due to environmental damage caused by human activities so that the surface flow rate increases and the water catchment area decreases. This occurs in almost all watersheds in the country (Tjasyono, Juaeni, \& Harijono, 2007); (Suryanto, 2016); (Sekaranom, Nurjani, Harini, \& Muttaqin, 2020).

Severe flooding occurred in several districts and cities in Bengkulu Province in April 2019. One of the causes of flooding is the critical condition of water catchment areas due to a large number of conversions from forest to nonforest land and heavy rainfall. Water catchment areas are decreasing due to changes in land-use, and the increasing population, which also leads to increased land requirements.
Land that was once forest areas or water catchment areas has been converted into non-forest areas. As a result, the area that could hold large amounts of water is reduced. Mase (2020) presented the effect of flood and slope stability along the Muara Bangkahulu subwatershed, which is part of the city of Bengkulu City. Nurohmah et al. (2014); Mase \& Fathona ( 2017 ) concluded that Muara Bangkahulu, as part of Bengkulu City, is very susceptible to flooding because the areas are dominated by alluvial deposit with low permeability characteristic. One way to identify water catchment areas is by knowing the parameters involved (Hastono, Sudarsono, \& Sasmito, 2012).

Efforts to conserve the critical condition of water catchment areas can be carried out properly when objective information on their conditions can be identified thoroughly (Gibbs \& Salmon, 2015). The provision of such data and information is necessary, especially to support an efficient strategy formula in the hope that references can be obtained in the allocation of resources proportionally. This means that to overcome the problem of the criticality of water catchment areas, the LCWCA (stand for the Level of Critical Water Catchment Area) map is required to overcome the critical importance of watersheds in such a way that priority areas for treatment, action, and estimates of the number of resources needed can be identified. However, the LCWCA Map's preparation describing the actual conditions may take a long time, much resources, and funds (Sulistyo et al., 2018). To overcome this problem, a model was used to map its 
distribution without conducting a direct survey. The Ministry of Forestry developed a mapping model to address critical watersheds and implemented it (Ministry of Forestry, 2009). The model is presented in Figure 1.

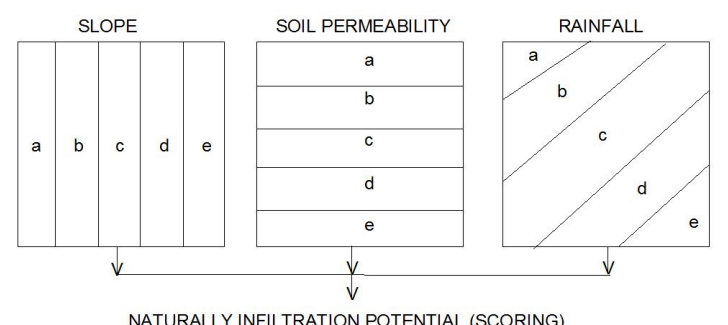

NATURALLY INFILTRATION POTENTIAL (SCORING)

\begin{tabular}{|c|c|c|c|c|c|c|c|}
\hline $\begin{array}{l}\text { Score of Infiltration } \\
\text { Potential }\end{array}$ & Score S & $\mathrm{umm}$ & ation & & & cription & Notation \\
\hline$a=5$ & 3 & 2 & 4 & 5 & & tra Slightly & $\mathrm{e}$ \\
\hline$b=4$ & 6 & 7 & 7 & 8 & & ightly & $d$ \\
\hline$c=3$ & 9 & 10 & & 11 & & oderately & c \\
\hline$d=2$ & 12 & 13 & & 14 & & ghly & $b$ \\
\hline$e=1$ & & & & 15 & & tra Highly & a \\
\hline & & & & & POV & ERLAY & \\
\hline $\begin{array}{l}\text { LANDUSE } \\
\text { (Actual Infiltration) }\end{array}$ & & & & & & & \\
\hline$A=$ Very large & aA & $\mathrm{aB}$ & $\mathrm{ac}$ & $\mathrm{aD}$ & $\mathrm{aE}$ & & Good \\
\hline$B=$ Large & $b B$ & $b c$ & $\mathrm{bD}$ & $b E$ & $\mathrm{bA}$ & & Naturally Normal \\
\hline$C=$ Medium & $\mathrm{cC}$ & $c D$ & $c E$ & $c A$ & $\mathrm{CB}$ & & Start Critical \\
\hline $\mathrm{D}=$ Slightly Small & $\mathrm{dD}$ & $\mathrm{dE}$ & $d A$ & $d B$ & $d C$ & & Slightly Critical \\
\hline$E=$ Small & eE & $\mathrm{eA}$ & $\mathrm{eB}$ & ec & $\mathrm{eD}$ & & Very Critical \\
\hline
\end{tabular}

Figure 1. LCWCA Model (Ministry of Forestry, 2009)

LCWCA is defined as :

LCWCA $=$ Potential Infiltration + Actual Infiltration

$(1)$

To calculate the Potential Infiltration, transformation factors derived from Slope, Soil Permeability, and Rainfall data are required. While to determine the Actual Infiltration, transformation factors is derived from Land Use data. Therefore, in full, LCWCA is formulated as:

$\mathrm{LCWCA}=\left(\mathrm{fc} \_\mathrm{S}+\mathrm{fc} \_\mathrm{SP}+\mathrm{fc} \_\mathrm{R}\right)+\mathrm{fc} \_\mathrm{LU}$

Where:

fc_S = transformation factor derived from Slope data

fc_SP = transformation factor derived from Soil

Permeability data

fc_R $\mathbf{R}=$ transformation factor derived from Rainfall data

fc_LU = transformation factor derived from Landuse data

The logical idea is that the higher the infiltration rate, the lower the runoff water level. Therefore, the flood discharge can decrease, and conversely, the base-flow can increase and the groundwater reserves. The catchment area identification technique can be analyzed using the map overlay method using Geographical Information Systems (GIS) techniques (DeMers, 2008). The magnitude of the transformation value can be expressed quantitatively or qualitatively as follows (Ministry of Forestry, 2009):

(a) Topography

From the available slope map derived from the topographic map, transformation can be determined based on its effect on the infiltration rate, as presented in Table 1.
Table 1. The relationship between slope and infiltration rate

\begin{tabular}{cclcc}
\hline Class & $\begin{array}{c}\text { Slope } \\
(\%)\end{array}$ & Description & \multicolumn{2}{c}{ Transformation factor } \\
\cline { 4 - 5 } & & & $\begin{array}{c}\text { Infiltration } \\
(\mathrm{fc})\end{array}$ & Notation \\
\hline I & $<8$ & Flat & $>0.8$ & $\mathrm{~A}$ \\
II & $8-15$ & Sloping & $0.7-0.8$ & $\mathrm{~B}$ \\
III & $15-25$ & Undulating & $0.5-0.7$ & $\mathrm{C}$ \\
IV & $25-40$ & Steep & $0.2-0.5$ & $\mathrm{D}$ \\
V & $>40$ & Very Steep & $<0.2$ & $\mathrm{E}$ \\
\hline
\end{tabular}

(b) Soil

In this case, it is necessary to conduct soil characteristics and geohydrology tests, which are then transformed based on their relationship to infiltration (soil permeability) with the following classification (Table 2).

Table 2. The relationship between soil permeability and infiltration value

\begin{tabular}{clccc}
\hline Class & Description & $\begin{array}{c}\text { Permeability } \\
(\mathrm{cm} / \text { hour })\end{array}$ & \multicolumn{2}{c}{ Transformation factor } \\
\cline { 4 - 5 } & & & $\begin{array}{c}\text { Infiltration } \\
(\mathrm{fc})\end{array}$ & Notation \\
\hline I & Fast & $>12.7$ & $>0.45$ & $\mathrm{~A}$ \\
II & Moderately & $6.3-12.7$ & $0.20-0.45$ & $\mathrm{~B}$ \\
& Fast & & & \\
III & Moderate & $2.0-6.3$ & $0.10-0.20$ & $\mathrm{C}$ \\
IV & $\begin{array}{l}\text { Moderately } \\
\text { Slow }\end{array}$ & $0.5-2.0$ & $0.04-0.10$ & $\mathrm{D}$ \\
V & Slow & $<0.5$ & $<0.04$ & $\mathrm{E}$ \\
\hline
\end{tabular}

(c) Rainfall

Potentially, infiltration is more important for the rain with a longer period. Concerning the infiltration, the rain factor was developed as "rainfall infiltration" or abbreviated as "RI," namely the annual rainfall multiplied by the number of rainy days divided by 100 . The results of the RI value calculation in relation to the potential infiltration can be classified as presented in Table 3 .

Table 3. Classification of the value of rainfall infiltration

\begin{tabular}{clcc}
\hline Class & Description & $\begin{array}{l}\text { Rainfall } \\
\text { Infiltration }\end{array}$ & Notation \\
\hline I & Low & $<2,500$ & $\mathrm{~A}$ \\
II & Moderate & $2,500-3,500$ & $\mathrm{~B}$ \\
III & Slightly High & $3,500-4,500$ & $\mathrm{C}$ \\
IV & High & $4,500-5,500$ & $\mathrm{D}$ \\
V & Very High & $>5,500$ & $\mathrm{E}$ \\
\hline
\end{tabular}

(d) Land-use type

Land use, especially the type of cover vegetation, influences infiltration in three forms: roots and pores increase soil permeability, vegetation retains runoff, and reduces the amount of percolated water through transpiration. Furthermore, vegetation also affects erosion through several processes. The tree canopy changes the rainfall's erosive energy that changes the raindrops' speed and size. The factors that play a role include crown height, crown thickness, 
Table 4. Actual infiltration

Classification

\begin{tabular}{clcl} 
Class & Description & Notation & \\
I & Very Large & A & Primary Forest \\
II & Large & B & Production forest, plantation \\
III & Medium & C & Schrub, meadow \\
IV & Slightly Small & D & Horticultural plants \\
V & Small & E & The settlement, paddy field \\
\hline
\end{tabular}

thickness, litter produced, grass, and herbs as ground cover. Considering the role of vegetation or land use, the actual infiltration level values qualitatively can be classified as presented in Table 4.

(e) Classification of Water Catchment Area Conditions After transforming the values and evaluating the components mentioned above, the condition of the catchment area can be classified by comparing the potential infiltration value with the actual infiltration value and the actual erosion value. The criteria used are as follows:

Good Condition, if the actual infiltration value is greater than the potential infiltration value, for example, from $\mathrm{E}$ to $\mathrm{A}$, or from $\mathrm{D}$ to $\mathrm{B}$, etc.

Natural Normal Condition that is, if the actual infiltration value is the same or remains as the potential infiltration value, for example, from $\mathrm{B}$ to $\mathrm{B}$, or from $\mathrm{C}$ to $\mathrm{C}$, etc.

Begin in a Critical Condition, if the actual infiltration value has dropped one level from its potential infiltration value, for example, from $\mathrm{A}$ to $\mathrm{B}$, or from $\mathrm{C}$ to $\mathrm{D}$, etc.

Rather Critical Condition, if the actual infiltration value has dropped two levels from the potential infiltration value, such as from $A$ to $C$, or from $B$ to $D$, etc.

Critical Condition, namely if the actual infiltration value has decreased by three levels from the potential infiltration value, for example, from $\mathrm{A}$ to $\mathrm{D}$ or from $\mathrm{B}$ to E.

Very Critical Condition, if the actual infiltration value changes from very large to very small, for example, from $\mathrm{A}$ to $\mathrm{E}$.

The LCWCA model is widely used in Indonesia by both practitioners and academicians. Guvil et al. (2018) analyzed the LCWCA in Padang City, West Sumatra, while Hidarto et al. (2013) analyzed LCWCA in the Lemau watershed, Bengkulu. Meanwhile, Rhochim (2017) analyzed LCWCA in Sukoharjo Regency, Central Java. Other researchers (Wahyuni et al., 2017) analyzed LCWCA in the Malino Hulu Sub-watershed, Gowa Regency, South Sulawesi. The research carried out by several of the researchers mentioned above was only stopped at information and dissemination of the LCWCA. However, there is another step for this research, namely determining the Potentially Flooded Area Map derived from LCWCA and comparing it with the Existing Flood Map in such a way that the level of accuracy will be known. This study aims to determine the model's accuracy for determining the Potentially Flooded Area Bengkulu City, which was derived from the LCWCA model.

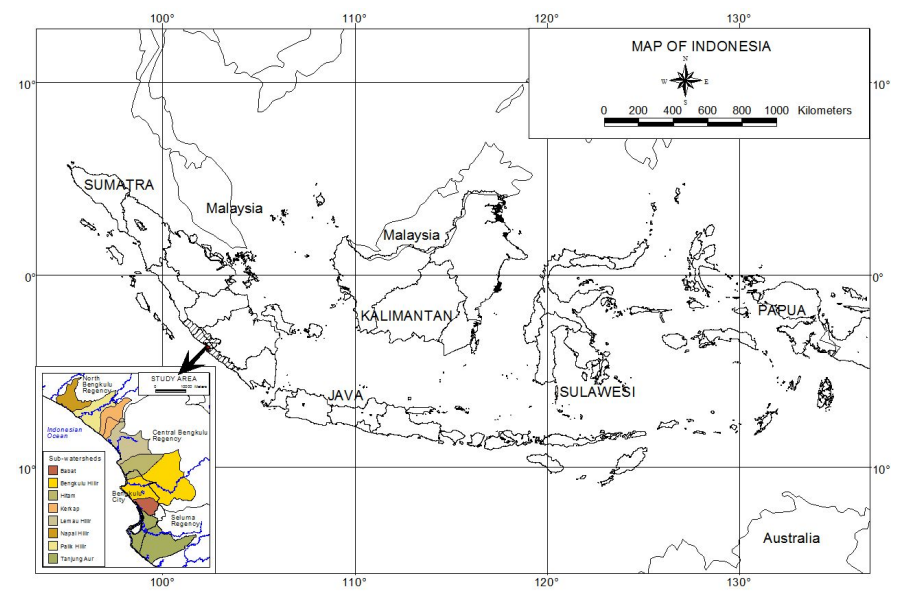

Figure 2. The Study Area

\section{Methods}

The study area is around Bengkulu City, which includes Seluma, Central Bengkulu, North Bengkulu regencies, and Bengkulu City, between $102.04^{\circ}$ and $102.51^{\circ}$ East between $3.47^{\circ}$ and $4.03^{\circ}$ South. The studied areas consist of 8 subwatersheds, namely. Babat; Bengkulu Hilir; Hitam; Kerkap; Lemau Hilir; Napal Hilir; Palik Hilir; and Tanjung Aur (Figure 2), while the flow diagram of the study is presented in Figure 3.

The main data required includes the Map of Land Use, Soil and Land Units, Watershed, Slope, and Rainfall Data. Meanwhile, the software and research tools include ArcView version 3.3 and ArcGIS version 10.3 and tools for vectorbased data analysis and map layout creation, Binoculars, compasses, ring samples, drills, gauges, and GPS field equipment; and other equipment that helps to facilitate activities.

An overlay analysis was carried out in the analysis stage to determine the LCWCA map using equations (1) and (2) and determine the Potentially Flooded Area. Then, the overlaying was carried out with the existing Flood Map.

If Model A is a Map is a modeling Potential Flooded Areas derived from the LCWCA model, and if Model B is an Existing Flood Map (which already exists), then a Model Test can be performed to determine the level of accuracy, that is by overlaying the two. A similar technique was carried out by Purwandari, Hadi, \& Kingma (2011).

In this study, the level of accuracy is defined as (modified from Stehman \& Czaplewsky, 1997):

The Level of Accuracy $=\underline{\text { FAP }} \times$ FAE $100 \%$

FAP is the overlaps areas between the Existing Flood Map and the Potential Flooded Area Map, while FAE is the area on the Existing Flood Map. Daels \& Anthrop (1981) state 


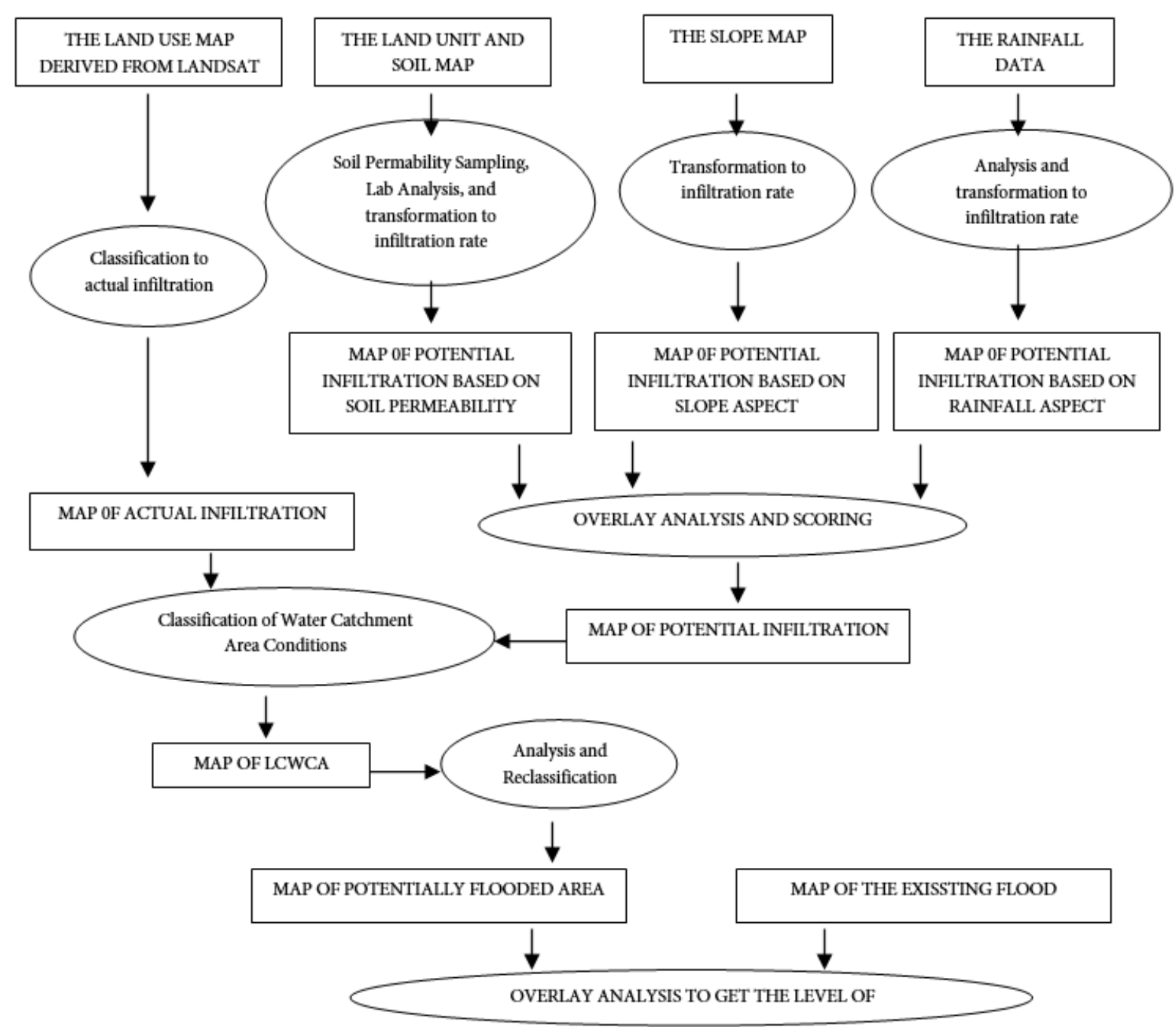

Figure 3. Flow diagram of the study

Table 5. Category of Level of Accuracy (Justice in Townshend, 1981)

\begin{tabular}{ll}
\hline Level of Accuracy (\%) & Remarks \\
\hline$>85$ & Good \\
$70-85$ & Moderate \\
$<70$ & Poor \\
\hline
\end{tabular}

that the model is supposedly good if it has an accuracy level of $\geq 80 \%$, while Justice in Townshend (1981) divides the level of accuracy into three categories (Table 5).

\section{Result and Discussion}

Input Data for the Analysis of the Critical Level of Water Catchment Areas

It was mentioned earlier that analyzing the LCWCA requires data input on Potential Infiltration and Land Use while calculating the Potential Infiltration required parameters of Slope, Soil Permeability, and Rainfall. The results of the analysis for each of these data are described in the following sections, respectively. The input maps for LCWCA analysis in the area around Bengkulu City are presented in Figure 4.

1. Topography and Potential Infiltration of Land Slope
Aspects

The analysis of the topographic map converted into a slope map, which were transformed according to their effect on the infiltration rate, is shown in Table 6. As stated at the beginning of the previous chapter, the area around Bengkulu City is dominated by the region, a Flat slope class (amounting to $98.74 \%$ ) followed by Sloping (by $1.26 \%$ ). From the slope aspect, it can be seen that $98.74 \%$ of the study area has a Very Good potential infiltration. This means that when it rains, the water tends to infiltrate into the ground. The Map of the Potential Infiltration based on the Aspect of the Slope is presented in Figure 4 (a).

\section{Permeability and Potential Infiltration from Permeability} Aspects

99 soil samples were collected from the field based on the land unit map for the entire province. The soil samples were then analyzed in the laboratory to obtain the soil permeability value. The results of the permeability analysis of transformed soils as a function of their effect on the infiltration rate in a study area are shown in Table 7 . The study area is dominated by the soil permeability class, Slightly Slow (by 40.6\%), followed by Moderate (by 32.2\%), Moderately Fast (by 18.1\%), and Fast (by 9.2\%). From the aspect of soil permeability, it can be seen that $72.6 \%$ of the 


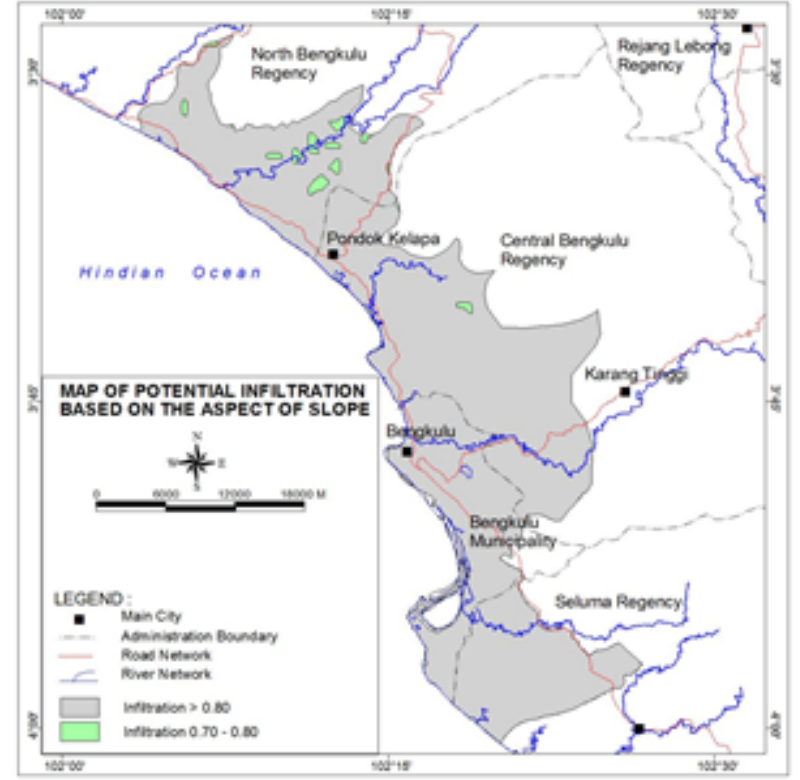

(a)

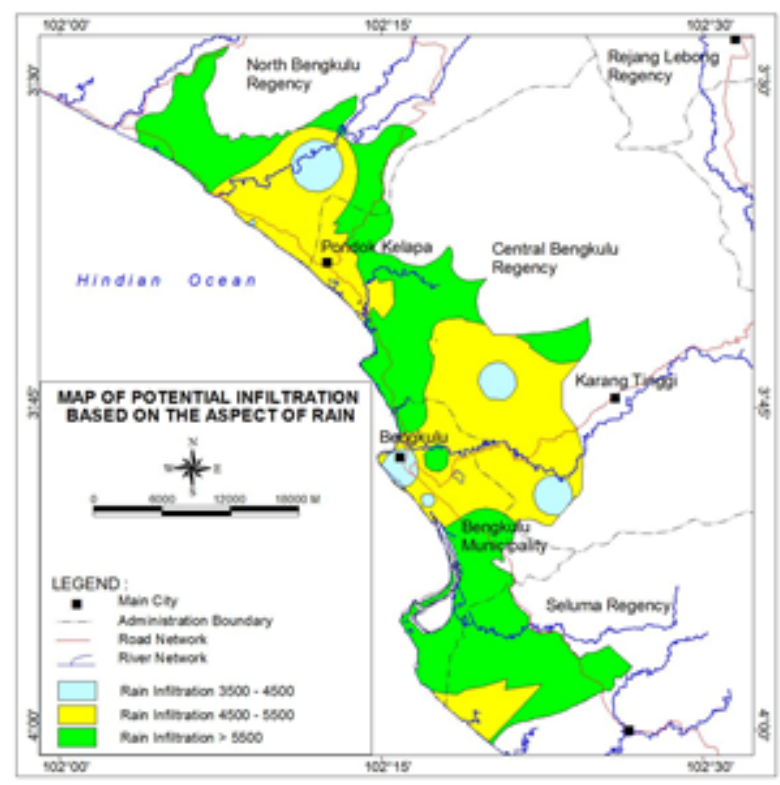

(c)

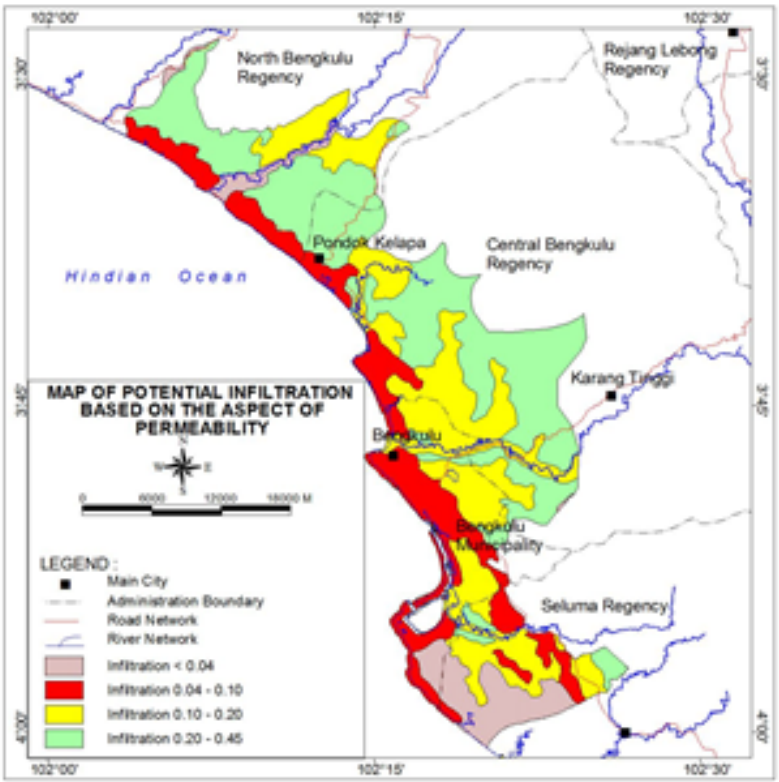

(b)



(d)

Figure 4. Input maps for LCWCA analysis in the area around Bengkulu City

Table 6. The area of slope and potential infiltration rate around Bengkulu City

\begin{tabular}{|c|c|c|c|c|c|c|}
\hline \multirow{2}{*}{ Class } & \multirow{2}{*}{ Slope $(\%)$} & \multirow{2}{*}{ Description } & \multicolumn{2}{|c|}{ Transformation factor } & \multicolumn{2}{|c|}{ Areas } \\
\hline & & & Infiltration $(\mathrm{fc})$ & Notation & Hectares & $\%$ \\
\hline $\mathrm{I}$ & $<8$ & Flat & $>0.8$ & A & $68,563.4$ & 98.74 \\
\hline II & $8-15$ & Sloping & $0.7-0.8$ & B & 874.6 & 1.26 \\
\hline \multicolumn{5}{|c|}{ Total } & $69,437.9$ & 100.0 \\
\hline
\end{tabular}

study area has Moderate and Slightly Slow potential infiltrations. This means that when it rain, the water tends to infiltrate into the ground. The Potential Infiltration Map based on Soil Permeability Aspects is presented in Figure 4 (b).

3. Rainfall and Potential Infiltration from Rain Infiltration
Aspects

A total of 111 rainfall stations spread across Bengkulu Province were used to analyze rainfall and infiltration rain. The rainfall data recorded in 2018 comes from BMKG Pulau Baai, Bengkulu. The coordinates of each precipitation station are drawn on the map, and at each of these points, the rainfall 
Table 7. Soil permeability area and potential infiltration rate around Bengkulu City

\begin{tabular}{|c|c|c|c|c|c|c|}
\hline \multirow{2}{*}{ Class } & \multirow{2}{*}{$\begin{array}{c}\text { Permeability }(\mathrm{cm} / \\
\text { hour })\end{array}$} & \multirow{2}{*}{ Description } & \multicolumn{2}{|c|}{ Transformation factor } & \multicolumn{2}{|c|}{ Areas } \\
\hline & & & Infiltration $(\mathrm{fc})$ & Notation & Hectares & $\%$ \\
\hline $\mathrm{I}$ & $>12.7$ & Fast & $>0.45$ & $\mathrm{~A}$ & $6,375.4$ & 9.2 \\
\hline II & $6.3-12.7$ & Moderately Fast & $0.20-0.45$ & B & $12,538.8$ & 18.1 \\
\hline III & $2.0-6.3$ & Moderate & $0.10-0.20$ & C & $22,363.1$ & 32.2 \\
\hline IV & $0.5-2.0$ & Slightly Slow & $0.04-0.10$ & $\mathrm{D}$ & $28,160.6$ & 40.6 \\
\hline
\end{tabular}

Table 8. Potential Infiltration Area based on Rainfall Infiltration Aspect around Bengkulu City

\begin{tabular}{clcrrr}
\hline Class & Description & Rainfall Infiltration & Notation & \multicolumn{2}{c}{ Areas } \\
\cline { 5 - 6 } & & & & Hectares & $\%$ \\
\hline I & Low & $2.500-3.500$ & $\mathrm{~A}$ & 0 & 0,0 \\
II & Moderately & $3.500-4.500$ & $\mathrm{~B}$ & 0 & 0,0 \\
III & Slightly High & $4.500-5.500$ & $\mathrm{C}$ & $4,126.7$ & 5.9 \\
IV & High & $>5.500$ & $\mathrm{D}$ & $30,280.8$ & 43.6 \\
V & Very High & Total & & $35,030.5$ & 50.5 \\
\hline
\end{tabular}

Table 9. Land Use Area and Actual Infiltration Rate Value around Bengkulu City

\begin{tabular}{|c|c|c|c|c|}
\hline \multirow{2}{*}{ Land Use Type } & \multicolumn{2}{|c|}{ Classification } & \multicolumn{2}{|l|}{ Areas } \\
\hline & Description & Notation & Hectares & $\%$ \\
\hline Open Land & Very Small & $\mathrm{E}$ & 2,688 & 0.5 \\
\hline Pond & Very Small & $\mathrm{E}$ & 434.9 & 0.6 \\
\hline Paddy Field & Very Small & $\mathrm{E}$ & $2,933.5$ & 4.2 \\
\hline Swamp & Very Small & $\mathrm{E}$ & 28.0 & 0.0 \\
\hline Dryland Mix Agriculture & Small & $\mathrm{D}$ & $41,321.7$ & 59.5 \\
\hline Dryland Agriculture & Small & $\mathrm{D}$ & 368.7 & 0.5 \\
\hline Plantation & Large & B & $7,924.1$ & 11.4 \\
\hline Settlement & Very Small & $\mathrm{E}$ & $8,342.6$ & 12.0 \\
\hline Swamp & Very Small & $\mathrm{E}$ & 897.3 & 1.3 \\
\hline Shrub & Large & B & $6,715.8$ & 9.7 \\
\hline Port & Very Small & E & 71.0 & 0.1 \\
\hline Waterbody & Very Small & $\mathrm{E}$ & 400.3 & 0.6 \\
\hline \multicolumn{3}{|c|}{ Total } & $69,437.9$ & 100,0 \\
\hline
\end{tabular}

amount and infiltration data are written. The IDW (Inverse Distance Weighted) spatial interpolation using the ArcGis Program was carried out so that the rainfall map and the potential infiltration map are preserved under the aspect of rain infiltration. The results of rainfall analysis that have been transformed based on its effect on the infiltration rate in a study area are presented in Table 8 . The study area is dominated by a Very High rain infiltration class (by 50.5\%), followed by High (by 43, 6\%), while the rest (5.9\%) is Slightly High. From this aspect of rain infiltration, it can be seen that $94.1 \%$ of the study area has a High and Very High potential infiltration. Due to a large amount of rain infiltration, rainwater goes straight to the soil's surface when vegetation does not catch it, and some cause erosion when there is nothing to hold it back into the ground. Potential Infiltration
Map based on Rain Infiltration Aspect is presented in Figure 4 (c).

\section{Land Use Type and Actual Infiltration}

The land-use area based on the interpretation of the Landsat OLI images (Table 9) shows that the city of Bengkulu is affected by the existence of Dryland Mix Agriculture (59.5\%), Settlements (12.0\%), Plantation (11.4\%), and Shrub (9.7\%), while other types of land use averaged less than 5\%. Map of the Actual Infiltration is presented in Figure $4(\mathrm{~d})$.

From the spatial analysis results, it can be concluded that around the city of Bengkulu, which has the potential for flooding, is the LCWCA area with the classification of Rather Critical (17.3\%) and Critical (0.22\%). The two areas cover $12,148.2$ hectares or $17.52 \%$ of the studied area. The 


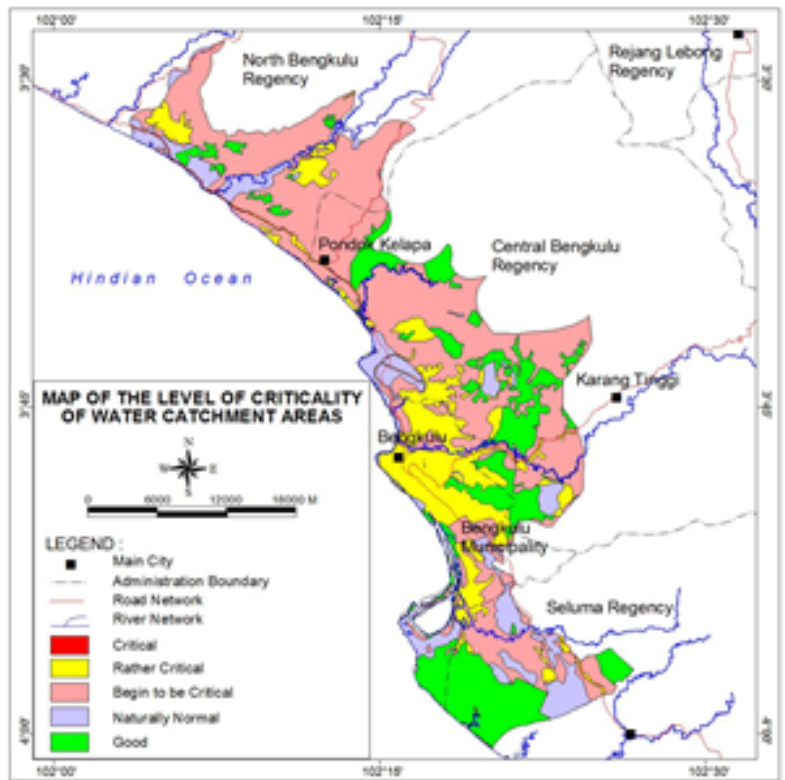

(a)

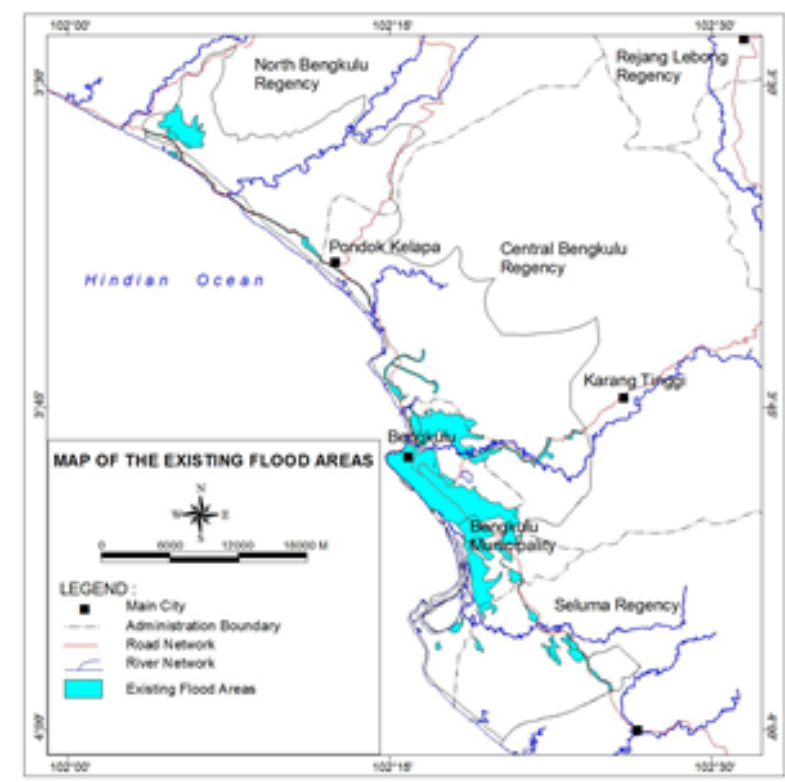

(c)

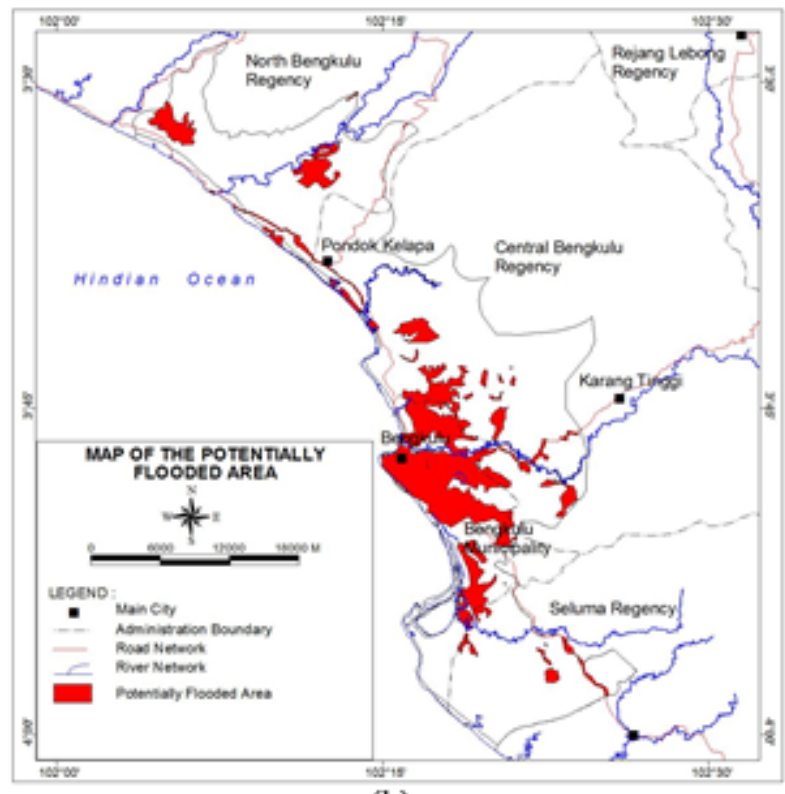

(b)

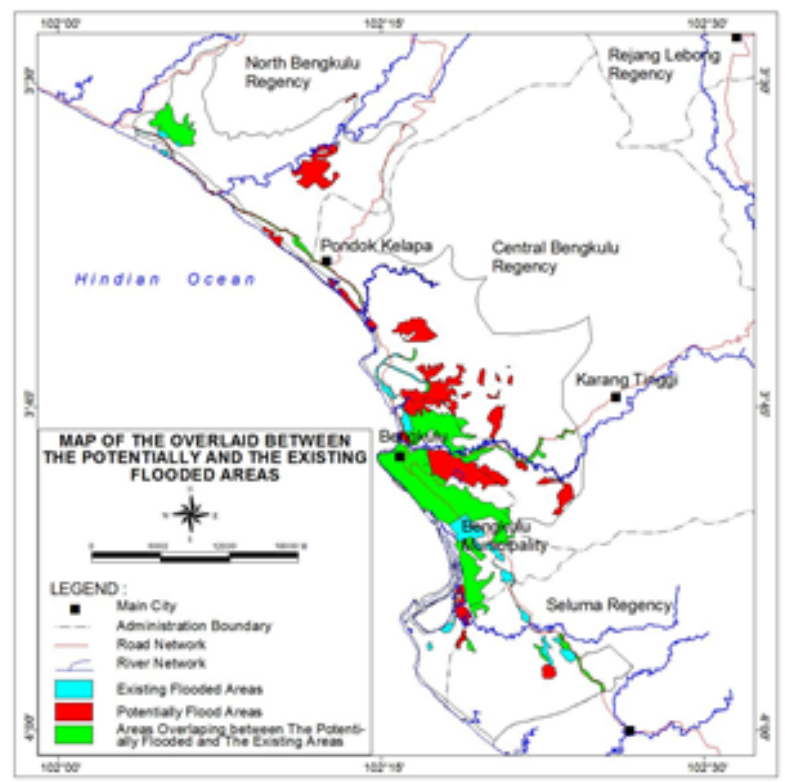

(d)

Figure 5. Map of LCWCA analysis results around Bengkulu City

Table 10. The Areas of LCWCA around Bengkulu City

\begin{tabular}{lrr}
\hline \multirow{2}{*}{ Description } & \multicolumn{2}{c}{ Areas } \\
\cline { 2 - 3 } & \multicolumn{1}{c}{ Hectares } & \multicolumn{1}{c}{$\%$} \\
\hline Critical & 154.7 & 0.22 \\
Rather Critical & $11,993.5$ & 17.3 \\
Begin to Critical & $35,380.6$ & 51.0 \\
Naturally Normal & $8,087.4$ & 11.6 \\
Good & $13,821.8$ & 19.9 \\
\multicolumn{1}{c}{ Total } & $69,437.9$ & 100.0 \\
\hline
\end{tabular}

Potentially Flooded Area Map Bengkulu City is presented in Figure 5 (b).

Results of the Accuracy of LCWCA Model for Flood Mitigation

To determine the accuracy of the LCWCA model in assessing the potential for flooding, the Potentially Flooded Area Map around Bengkulu City is overlaid with the Existing
Flood Map used as a reference shown in Figure 5 (c).

The Existing Flood Map around Bengkulu City is spatially analyzed and derived from the Ecosystem Services-based Indication Map of the Environmental Carrying Capacity of Bengkulu Province compiled by the Sumatra Ecoregion Development Control Center (P3E Sum), Ministry of Environment and Forestry. The flood area on the map is $8,317.8$ hectares or $12.0 \%$ of the study area.

The overlapping results between the Potential Flooded Area Map analysis results from LCWCA and the Existing Flood Map Bengkulu City are presented in Figure 5 (d). The map is presented in both overlap and non-overlapping areas. The overlap shows how precise it is by calculating the area and calculating the area that does not overlap, as shown in equation (3). The accuracy results for each sub-watershed are presented in Table 11.

From Table 11, it can be concluded that out of the eight sub-watersheds around the city Bengkulu studied, there were two sub-watersheds with Good accuracy, three subwatersheds with moderate, and three sub-watersheds with 
Table 11. The accuracy results of the Potentially Flooded Area analysis results from LCWCA for each Sub-watershed Bengkulu City

\begin{tabular}{llcc}
\hline Sub-Watershed & Watershed & Accuracy $(\%)$ & Status \\
\hline Babat & Babat & 74.1 & Moderate \\
Bengkulu Hilir & Bengkulu & 97.9 & Good \\
Hitam & Hitam & 53.6 & Poor \\
Kerkap & Kerkap & 100.0 & Good \\
Lemau Hilir & Lemau & 60.4 & Poor \\
Napal Hilir & Napal & 81.6 & Moderate \\
Palik Hilir & Palik & 77.7 & Moderate \\
Tanjung Aur & Tanjung Aur & 68.4 & Poor \\
\hline
\end{tabular}

Poor accuracy.

Purwandari, Hadi, and Kingma (2011) achieved an accuracy of $91.7 \%$ by comparing the potentially flooded map in part of the city of Surakarta from the model with the existing flooded map.

Note that the LCWCA model does not directly target the flood model. Therefore, the parameters involved in the model do not yet include all possible parameters at the origin of the flood. Tsakiris (2014) suggested that modeling should be based on the fully dynamic approach and not on simplifications, which are attractive but not appropriate. For example, kinematic wave models can perform satisfactorily in steep areas with simple topography but fail to work accurately in mild terrains with complex topography. Furthermore, Teng et al. (2017) revealed that when combined with climate models, hydrological models, and river models, the application of flood modeling has been extended to modeling that aims to formulate climate adaptation and risk mitigation strategies.

This is the only research that tries to use the LCWCA model to get the potentially flooded map and examine the accuracy obtained compared to the existing flooded map.

Besides the above reasons, some of the possible reasons for being the source of the level of accuracy are:

\section{Land Use Type Classification}

The type of land-use class to determine the actual infiltration level value in the LCWCA model is too simple and global (meaning the map scale is small scale), as presented in Table 4. For example, the type of land use for Plantation does not specify its type. The types of land use for these plantations can be detailed, for example, Oil Palm and Rubber Plantations. This can be explained in more detail depending on the age group, as the age difference affects the crown and water infiltration rate into the soil.

Usually, the type of land use is generally interpreted from satellite imagery. With the development of high-resolution satellite imagery, it is easy to get more detailed information about land use types. However, the criteria for land use types in the LCWCA model are too general; the detailed information obtained seems useless because the type of land use obtained must be adapted according to the type of land use already listed in the table. Therefore, the land use type class to determine the actual infiltration rate value in the LCWCA model needs to be detailed.

The Use of Vector Data Format in Modeling
All input data used to perform LCWCA analysis uses a vector-based data format. DeMers (2008) states that the presentation of geoinformation in a vector data model assumes that a mapping unit is homogeneous. An area with homogeneous characteristics can be obtained by way of grouping or classification and simplification. This grouping or classification and simplification are carried out subjectively so that sometimes there is an oversimplification so that the actual terrestrial information variation is reduced or even lost.

For example, in the slope class. An area that has a slope of $<8 \%$ is called a Flat area. If the slope is between $0 \%$ and $8 \%$, it will be simplified to Flat. Therefore, the actual variation of the slope information is lost. The same example applies to soil permeability class and infiltration rain class.

In order to solve the above two problems, the data used should use the raster data format. The data obtained are not the result of any simplification but rather reflect variations in real earth data. Furthermore, the raster data format has advantages over the vector data format. Among others, there is the ease in modeling analysis (DeMers, 2008), the analysis was carried out objectively (Hadmoko, 2007), and can describe variations in natural conditions or terrestrial information in a more accurate way because ground information is presented in small sizes (DeMers, 2008); (Wang, Wente, Gertner, \& Anderson, 2002).

All data used in modeling is presented in raster data format, but not in raster data, which results from the analysis using the Vector to Raster Conversion algorithm. However, raster data is generated by performing spatial interpolation analysis. The spatial interpolation uses points with known values to estimate the value of another attribute (Chang, 2008). If the rainfall data from a nearby rainfall station is known, the rainfall value can be estimated at locations where the data was not recorded. In GIS applications, spatial interpolation is applied to raster data by estimating all cells. Furthermore, its results can be used to create surface data from sample points in such a way that they can be used for analysis and modeling.

Using the fully raster-based data, Sulistyo, Gunawan, Hartono \& Danoedoro (2009) examine the USLE (Universal Soil Loss Equation) erosion model developed by Wischmeier and Smith (1978). It can be demonstrated that the erosion results calculated according to the model have high accuracy when compared to the actual erosion. Furthermore, several USLE parameters ( $\mathrm{R}$ factor, $\mathrm{C}$ factor, LS factor, and $\mathrm{K}$ factor) and Percentage of Canopy was also assessed independently 
using the fully raster-based data with good results (Sulistyo, Gunawan, Hartono \& Danoedoro, 2011; 2013; 2015); (Sulistyo, 2011).

Using the fully raster-based data Sulistyo, et al. (2017) identified the errors in the levels of the degraded land model developed by the Ministry of Forestry, and it was suggested that to reformulate the model that has been implemented. Sulistyo et al. (2018) and Sulistyo et al. (2020) also succeeded in proving that the use of the fully raster-based data can be performed in the field of cultivation of sea cucumber (Holothuria scabra). But, for some places where the available data is limited to apply the more complicated flood model, the LCWCA model can be an alternative to apply while improving the quality of the input data.

\section{Conclusion}

In the eight sub-watersheds around Bengkulu City, there were two sub-watersheds with Good accuracy (> 85\%), which means that there was $>85 \%$ overlap between areas on the Potentially Flooded Area Map as a result of the analysis of The LCWCA with the area on the Existing Flood Map. There are three sub-watersheds with Moderate accuracy (70 - 85\%) and three sub-watersheds with Poor accuracy $(<70 \%)$.

\section{Acknowledgment}

The authors express profound gratitude to the Office of Research and Community Services of-Bengkulu University for financial support (Unggulan Scheme 2020, Contract Number 1990/UN30.15/PG/2020).

\section{References}

BNPB (2020). Data Kejadian Bencana (Disaster Event Data). Pusat Data Informasi dan Humas. Badan Nasional Penanggulangan Bencana. Jakarta.

Chang, K. T. (2008). Introduction to Geographic Information Systems, McGraw-Hill International Edition, New York, USA

Daels \& Antrop. (1981). Remote Sensing; Fundamental International Training Centre for Post Graduate Soil Scientist, Seminar of Regional Geography, State University of Ghent, Belgium.

DeMers, M. N. (2008). Fundamental of Geographic Information Systems. New York: John Wiley \& Sons.

Gibbs, H. K. \& Salmon, J. M. (2015). Mapping the world's degraded lands. Journal of Applied Geography, 57, 12-21.

Guvil, Q., Driptufany, D.M., \& Ramadhan, S. (2018). Analisis Potensi Daerah Resapan Air Kota Padang (Analysis of the Potential of Water Infiltration in Padang City), National Geomatics Seminar 2018: Use and Development of Geospatial Information Products to Support National Competitiveness, 671 -680 .

Hadmoko, D. S. (2007). Toward GIS-based integrated landslide hazard assessment: a critical overview. Indonesian Journal of Geography, 39, 55-77.

Hastono, F. D., Sudarsono, B. \& Sasmito, B. (2012). Identifikasi Daerah Resapan Air Dengan Sistem Informasi Geografis, Studi Kasus: Sub DAS Keduang (Identification of Infiltration Areas by using Geographical Information Systems, Case Study: Keduang Sub-watershed). Diponegoro University. Semarang.

Hindarto, K.S., Hidayat, M.F., \& Depari, E.K. (2013). Aplikasi Sistem Informasi Geografis Untuk Pemodelan Spasial Disain Tata Guna Lahan Dan Lemau Berdasarkan Tingkat Kekritisan Daerah Resapan (Geographical Information System Application for Spatial Modeling of Land Use Design and Lemau Based on the Level of Critical Water Catchment Area), Competitive Grant Research Report, LPPM, Bengkulu
University

Mase, L. Z. (2020). Slope Stability and Erosion-Sedimentation Analyses Along Sub-watershed of Muara Bangkahulu River in Bengkulu City, Indonesia. In E3S Web of Conferences (Vol. 148, p. 03002). EDP Sciences.

Mase, L. Z., \& Fathona, G. (2017), Estimation soil layers for some areas in Bengkulu City based on CPT approach, Teknosia, 3, 40 $-46$.

Ministry of Forestry. (2009). Peraturan Menteri Kehutanan RI Nomor : P. 32/Menhut-II/2009 tentang Tata Cara Penyusunan Rencana Teknik Rehabilitasi Hutan dan Lahan DAS (Regulation of the Minister of Forestry of the Republic of Indonesia Number: P. 32 / Menhut-II / 2009 concerning Procedures for the Preparation of Technical Plans for Forest and Watershed Rehabilitation). Jakarta, Ministry of Forestry.

Narulita, I., Rahmat, A. \& Maria, R. (2008). Aplikasi Sistem Informasi Geografi untuk Menentukan Daerah Prioritas Rehabilitasi di Cekungan Bandung (Geographic Information System Application for Determining Priority Areas for Rehabilitation in the Bandung Basin). Jurnal Riset Geologi dan Pertambangan, 18, 23-35.

Nurohmah, A., Priadmojo, A., Dewi, M. K., Satria, M. R., \& Saputra, N. (2014). Analysis of Regional Development in Connection with Multi Disaster Susceptibility in Bengkulu Province, Procedia-Social and Behavioral Sciences, 135, 70-75.

Oluwasegun, A.H. (2017). GIS Analysis of Flood Vulnerable Area in Benin-Owena River Basin Nigeria, Indonesian Journal of Geography, 49, 27-33.

Purwandari , T., Hadi, M.P., \& Kingma, N.C. (2011). A GIS Modelling Approach For Flood Hazard Assessment in part of Surakarta City, Indonesian Journal of Geography, 43, 63-80.

Rhochim, R. (2017). Identifikasi Daerah Resapan Air Dengan Menggunakan Sistem Informasi Geografis Di Kabupaten Sukoharjo (Identification of Water Infiltration Areas Using Geographical Information Systems in Sukoharjo Regency), Undergraduate Thesis, Faculty of Geography, Muhammadiyah University of Surakarta

Rosyidie, A. (2013). Banjir: Fakta dan Dampaknya, serta Pengaruh dari Perubahan Guna Lahan (Floods: Facts and Impacts, and Effects of Land Use Change. Journal of Urban and Regional Planning). Jurnal Perencanaan Wilayah dan Kota, 24, 241 - 249.

Sekaranom, A.B., Nurjani, E., Harini, R., \& Muttaqin, S. (2020). Simulation of Daily Rainfall Data using Articulated Weather Generator Model for Seasonal Prediction of ENSO-Affected Zones in Indonesia, Indonesian Journal of Geography, 52, 143153.

Stehman, S.V. \& Czaplewsky, R.L. (1997). Design and Analysis for Thematic Map Accuracy Assessment: Fundamental Principles, Remote Sensing of Environment, 64, 331-344.

Sulistyo, B. (2011). The effect of choosing different contour interval on a fully raster-based erosion modeling (The case in Merawu Watershed, Banjarnegara, Central Java). Jurnal Tanah Tropika, $16,258-266$.

Sulistyo, B. (2015). Pemodelan faktor K berbasis raster sebagai masukan pemodelan erosi Di DAS Merawu, Banjarnegara, Provinsi Jawa Tengah (Raster-based $\mathrm{K}$ factor modeling as an input for erosion modeling in the Merawu watershed, Banjarnegara, Central Java Province), Jurnal Manusia dan Lingkungan 22, 240-246

Sulistyo, B., Gunawan, T., Hartono \& Danoedoro, P. (2009). Toward a fully and absolutely raster-based erosion modeling by using RS and GIS. Indonesian Journal of Geography, 41:149-70.

Sulistyo, B., Gunawan, T., Hartono \& Danoedoro, P. (2011). Pemetaan faktor $\mathrm{C}$ yang diturunkan dari berbagai indeks vegetasi data penginderaan jauh sebagai masukan pemodelan erosi di DAS Merawu (Mapping the $\mathrm{C}$ factor derived from various vegetation indices from remote sensing data as input for modeling erosion in the Merawu watershed). Jurnal Manusia dan Lingkungan, 18:68-78.

Sulistyo, B., Gunawan, T., Hartono \& Danoedoro, P. (2013). 
Pemodelan persentase tajuk di DAS Merawu yang diturunkan dari berbagai indeks vegetasi data penginderaan jauh (Modeling of the percentage of canopy in the Merawu watershed derived from various vegetation indexes from remote sensing data). Forum Geografi, , 23-32.

Sulistyo, B., Gunawan, T., Hartono, Danoedoro, P. \& Martanto, R. (2017). Proposed Model on Levels of Degraded Land At Merawu Watershed, Banjarnegara Regency, Central Java Province, Indonesia, Biotropia, 24, 220-229.

Sulistyo, B., Purnama, D., Anggraini, M. \& Listyaningrum, N. (2020); Validating The Fully Raster-Based Suitability Model for Sea Cucumber (Holothuria scabra), IOP Conf. Ser.: Mater. Sci. Eng. 874012035 , July 2020.

Sulistyo, B., Purnama, D., Anggraini, M. , Hartono, D., Wilopo, M.D., Wulandari, U., \& Listyaningrum, N. (2018). Refining The Suitability Modeling of Sea Cucumber (Holothuria scabra) Using Fully Raster-Based Data, Forum Geografi, 1, 119-130.

Sulistyo. B. (2011). Pengaruh erosivitas hujan yang diperoleh dari rumus yang berbeda terhadap pemodelan erosi berbasis raster (Effect of rain erosivity obtained from different formulae on raster-based erosion modeling). Agritech, 31, 250-259.

Suryanto, D. (2016). Tanah Airku Salah Kelola Hujan (My Motherland Manages the Rain Wrongly). Yogyakarta.

Teng, J., Jakeman, A.J., Vaze, J., Croke, B.F.W., Dutta, D., \& Kim, S. (2017). Flood inundation modelling: A review of methods, recent advances and uncertainty analysis, Environmental Modelling \& Software, 90, 202-214.

Tjasyono, B., Juaeani, I. \& Harijono. S. W. B. (2007). Proses Meteorologis Bencana Banjir di Indonesia (Meteorological Process of Flood Disaster in Indonesia). Jurnal Meteorologi dan Geofisika, 8, $64-78$.

Tsakiris, G. (2014). Flood risk assessment: concepts, modelling, applications, Nat. Hazards Earth Syst. Sci. Discuss, 2, 261-286.

Wahyuni, Arsyad, U., Bachtiar, B. \& Irfan, B. (2017). Identifikasi Daerah Resapan Air di Sub Daerah Aliran Sungai Malino Hulu Daerah Aliran Sungai Jeneberang Kabupaten Gowa (Identification of Watershed Areas in the Upper Malino Watershed in the Jeneberang River Basin, Gowa Regency). Jurnal Hutan dan Masyarakat, 9, 93-104.

Wang, G., Wente, S., Gertner, G. Z. \& Anderson, A. (2002) Improvement in mapping vegetation cover factor for the universal soil loss equation by geostatistical methods with Landsat Thematic Mapper images. International Journal of Remote Sensing, 23, 3649-3667.

Wibowo, M. (2006). Model Penentuan Kawasan Resapan Air Untuk Perencanaan Tata Ruang Berwawasan Lingkungan (Water Infiltration Area Determination Model for Environmentally Friendly Spatial Planning). Jurnal Hidrosfer, $1,1-7$.

Wischmeier, W. H. \& Smith, D. D. (1978), Predicting Rainfall Erosion Losses : A Guide to Conservation Planning. Washington DC: USDA Agriculture Handbook. 